Kabankov Andrey Vasilievich, Dentist surgeon; tel.: +78127407581; e-mail: Viandr2007@yandex.ru

Garunov Musa Magomedovich, Senior Laboratory Assistant, Department of dentistry; tel.: +7921886312; e-mail: leondent@mail.ru Rumakin Vasiliy Petrovich, MD, Associate Professor of Departament of pathological anatomy; tel.: +78126709592; e-mail: vprumakin@rniito.ru

Borodulina Irina Ivanovna, MD, PhD, Professor, Department of oral and maxillofacial surgery; tel.: +78124957203; e-mail: borodulina59@mail.ru

ISSN - 2073-8137

\title{
COMPARISON OF THE EFFECTIVENESS OF VARIOUS SULPHUR-CONTAINING HEPATOPROTECTORS AGAINST CHRONIC ALCOHOLIZATION
}

\author{
Bykov I. M., Berberidy H. P., Popov K. A., Ermakova G. A., \\ Tsymbalyuk I. Yu., Esaulenko E. E., Denisova Ya. E., Azimov E. A. \\ Kuban State Medical University, Krasnodar, Russian Federation

\section{СРАВНЕНИЕ ЭФФЕКТИВНОСТИ РАЗАИЧНЫХ СЕРОСОАЕРЖАЩИХ ГЕПАТОПРОТЕКТОРОВ В КОРРЕКЦИИ ХРОНИЧЕСКОЙ ААКОГОАЬНОЙ ИНТОКСИКАЦИИ В ЭКСПЕРИМЕНТЕ}

\author{
И. М. Быков, Х. П. БербериАи, К. А. Попов, Г. А. Ермакова, \\ И. Ю. Цымбалюк, Е. Е. Есауленко, Я. Е. Аенисова, Э. А. Азимов
}

\section{Кубанский госУАарственный МеАицинский Университет, КрасноАар, Российская ФеАерация}

\begin{abstract}
Studies on the treatment of intoxication caused by prolonged use of alcohol are necessary. Herein, the influence of ademetionine, methionine and lipoic acid under various administration schemes on the course of chronic alcoholization was compared. The study was performed on 125 white nonlinear male rats (initial body mass: 220-250 g) divided into seven groups. Groups 2-7 underwent alcoholization for two months. The rats of groups 3-7 were administered ademetionine, methionine or lipoic acid. We determined herein that ademetionine injections had the most significant hepatoprotective and antioxidant effects, and they maintained the mitochondria in an adequate functional state. Methionine administration showed no cytoprotective effect, and it was characterized by mitochondrial dysfunction and a more significant increase in the activity of hepatic cytolysis markers. The lipoic acid injections had a significant antioxidant effect, but their cytoprotective effects were mild. On the basis of our findings, we concluded that the substances tested here mainly improved metabolic disorders induced by chronic alcoholization via maintenance of the detoxification and biosynthetic functions of the liver.
\end{abstract}

Keywords: alcoholization, oxidative stress, antioxidant system, methionine, lipoic acid, ademetionine

Проведено сравнительное исследование влияния адеметионина, метионина и разных схем введения липоевой кислоты на течение хронической алкогольной интоксикации. Исследование проведено на 125 белых нелинейных крысах-самцах с исходной массой 220-250 граммов, разделенных на 7 групп. Животные 2-7-й групп в течение 2 месяцев подвергались алкоголизации. Крысам 3-7-й групп с целью коррекции вводили адеметионин, метионин или липоевую кислоту. В результате проведенных исследований было установлено, что применение адеметионина оказывало наиболее выраженное гепатопротекторное и антиоксидантное действие, а также способствовало поддержанию адекватного функционального состояния митохондрий. Включение исследуемым животным метионина не оказывало цитопротекторного действия, а, напротив, характеризовалось еще более значительным увеличением активности маркеров цитолиза гепатоцитов в плазме крови и митохондриальной дисфункцией. Введение липоевой кислоты оказывало выраженное антиоксидантное действие, но цитопротекторный эффект был незначителен. Таким образом, ведущее значение для коррекции метаболических нарушений при хронической алкогольной интоксикации имела поддержка детоксикационной и биосинтетической функции печени.

Ключевые слова: алкогольная интоксикация, окислительный стресс, антиоксидантная система, метионин, липоевая кислота, адеметионин

For citation: Bykov I. M., Berberidi H. P., Popov K. A., Ermakova G. A., Tsymbalyuk I. Yu., Esaulenko E. E., Denisova Ya. E., Azimov E. A. COMPARISON OF THE EFFECTIVENESS OF VARIOUS SULPHUR-CONTAINING HEPATOPROTECTORS AGAINST CHRONIC ALCOHOLIZATION. Medical News of North Caucasus. 2019;14(3):523-527.

DOI - https://doi.org/10.14300/mnnc.2019.14129 
Для цитирования: Быков И. М., Бербериди Х. П., Попов К. А., Ермакова Г. А., Цымбалюк И. Ю., Есауленко Е. Е., Денисова Я. Е., АЗИмОв Э. А. СРАВНЕНИЕ ЭФФЕКТИВНОСТИ РАЗЛИЧНЫХ СЕРОСОДЕРЖАЩИХ ГЕПАТОПРОТЕКТОРОВ В КОРРЕКЦИИ ХРОНИЧЕСКОЙ АЛКОГОЛЬНОЙ ИНТОКСИКАЦИИ В ЭКСПЕРИМЕНТЕ. МеДИЦИНСКИЙ веСТнИК С верного Кавказа. 2019;14(3):523-527. DOI - https://doi.org/10.14300/mnnc.2019.14129

\author{
ALT - alanine aminotransferase \\ CAT - catalase \\ DC - diene conjugates \\ GPO - glutathione peroxidase
}

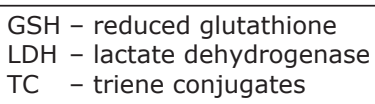

S ulphur-containing remedies with thiol groups such as cysteine and lipoic acid, as well as methionine with thioether groups and their derivatives, play essential roles in many biochemical functions of an organism. In addition to being proteinogenic amino acids, they are directly involved in the regulation of redox homeostasis of cells, energy metabolism, decontamination of xenobiotics, and biosynthesis of many biologically active agents including membrane phosphatidylcholines and bile acids $[1,2]$. Most of these effects reveal a close connection to the general liver mechanisms, which is why a comparative analysis of the hepatoprotective properties of sulphur-containing remedies and their derivatives within various experimental and clinical trials is relevant [3]. Nowadays, one of the most notable and effective hepatoprotectors is S-adenosyl-methionine (ademetionine), which is found in commercial formulations for oral and parenteral administration. It is an active form of methionine ready to donate the methyl group to decontamination or biosynthesis reactions $[4,5]$. Free methionine is not suitable for such extensive use, while its protective values are frequently underlined [6]. Lipoic acid is widely used in the treatment of diabetic polyneuropathy, but its effect on liver metabolism has also been established.

Furthermore, lipoic acid as a powerful antioxidant is used to ameliorate oxidative stress within a wide range of pathological conditions [7,8]. The optimal protection protocols and injection schemes for these remedies remain unclear. Discovering ways to ameliorate intoxication caused by long-term alcohol consumption is important because the human liver is the main target of ethanol. Hence, the effectiveness of sulphur-containing hepatoprotectors in the abovementioned conditions is of interest $[9,10]$.

The purpose of our study was to perform a comparative analysis of the influence of ademetionine, methionine, and lipoic acid in various administration schemes on the course of chronic alcoholization in experimental conditions.

Material and Methods. The study was performed on 125 white nonlinear male rats (initial mass of 220$250 \mathrm{~g}$ ) divided into seven groups. The rats of the control group (group 1, $\mathrm{n}=25$ ) were kept in the same conditions as the rest of the rats, but they did not undergo alcoholization and did not receive drugs or biologically active supplements. Groups 2-7 received $10 \%$ ethanol during the first week, $20 \%$ ethanol during the second week, and $30 \%$ ethanol until the end of the experiment. The duration of experiment was two months; within this time the ethanol solution substituted the usual water diet. The rats of groups 3-7 were injected with various sulphur-containing remedies against chronic alcoholization. The rats of group $3(n=15)$ were injected with $10 \mathrm{mg} /$ day of ademetionine (Heptral, Abbot Pharmaceutical, Italy). The rats of group $4(n=15)$ received $100 \mathrm{mg} / \mathrm{kg} /$ day of methionine per os with the drinking water. The rats of group $5(n=15)$ received $100 \mathrm{mg} / \mathrm{kg} /$ day lipoic acid (Octolipen, Farmstandart-Leksredstva, Russia) per os. The rats of group $6(n=15)$ were intraperitoneally injected with $50 \mathrm{mg} / \mathrm{kg} /$ day of lipoic acid during the first week, followed by oral administration of the remedy at $100 \mathrm{mg} / \mathrm{kg} /$ day. The animals of group $7(n=15)$ were intraperitoneally injected with $50 \mathrm{mg} / \mathrm{kg} /$ day of lipoic acid. The used dosage was substantiated by data reported in experimental studies $[4,6,11]$. The treatments started a month after the beginning of alcoholization and lasted till the end of the experiment; that is, the duration of the therapy was one month. The rats of group 2 received no remedies against alcoholization $(n=25)$.

All test animals were kept in a vivarium at the Kuban State Medical University (KubSMU). The animal management and all performed manipulations were in accordance with the «Rules of the European convention on the protection of vertebrate animals» (Strasbourg, 1986). The ethics committee of KubSMU approved the study (report № 54 of October 11, 2017).

Lactate dehydrogenase (LDH) activity in the blood plasma was determined by a kit from Vital Development Corporation (St. Petersburg, Russia). The content of reduced glutathione (GSH) in erythrocytes and catalase (CAT) activity and glutathione peroxidase (GPO) activity were determined as previously described [12]. The content of products of oxidative modifications of lipids both diene and triene conjugates (DC and TC) - in the blood plasma was measured. The mitochondria were sampled from the liver tissue by differential centrifugation in a sucrose environment $(0.25 \mathrm{M}$ sucrose, one $\mathrm{mM}$ EDTA and two $\mathrm{mM} \mathrm{MgCl} \mathrm{Mn}_{2} 20 \mathrm{mM}$ Tris- $\mathrm{HCl}$ buffer, $\mathrm{pH} 7.4$ ), as previously described $[13,14]$. The protein concentration of the collected fractions was determined using the Bradford technique. The membrane potential of the mitochondria in the collected fractions was determined with the cationic dye, Safranin O. The measurement of the fluorescence intensity in its energized (with rotenone and succinate added) and non-energized (with sodium azide added) state was performed using a CM2203 spectrofluorometer (SOLAR, Belarus) at excitation and emission wavelengths of $495 \mathrm{~nm}$ and $586 \mathrm{~nm}$, respectively. The potential membrane evaluation was performed as previously described $[14,15]$.

The data were statistically processed using Stat plus (AnalystSoft Inc., USA). The data are presented in the form of a median (Me), $25^{\text {th }}$ and $75^{\text {th }}$ percentiles ( $p 0.25$ / $\mathrm{p} 0.75)$. The Mann - Whitney U-test was used to determine the differences between the test groups. $p<0.05$ was considered statistically significant.

Results and Discussion. The current study revealed an increase in LDH and ALT activity in the blood plasma of rats after two months of alcoholization, which is characteristic of the development of liver cell damage. The LDH activity in the rats of group 2 increased by 2.5 -fold, while the ALT activity increased by 1.7 -fold compared with the control (Table 1). The intraperitoneal ademetionine injections provided sufficiently significant liver protection, as the LDH activity in the rats of group 3 did not differ 
from that in the rats of group 1, and the ALT activity increased by only 1.3 -fold. In contrast, methionine caused even higher increases in these indices compared with the control and group 2.

Table 1

Markers of liver cell damage in rats suffering from chronic alcoholization [Me (p0.25/p0.75)]

\begin{tabular}{|l|c|c|}
\hline \multirow{2}{*}{ Group } & \multicolumn{2}{|c|}{ Indices } \\
\cline { 2 - 3 } & LDH, units/L & ALT, units/L \\
\hline 1 (control) & $76.4(63.4 / 85.3)$ & $23.5(19.4 / 24.5)$ \\
\hline 2 & $193.6(175.5 / 220.1)^{*}$ & $40.2(36.8 / 48.9)^{*}$ \\
\hline 3 & $58.0(52.0 / 66.7)^{\wedge}$ & $30.8(26.8 / 32.0)^{* \wedge}$ \\
\hline 4 & $297.4(250.3 / 320.8)^{* \wedge}$ & $48.1(44.6 / 50.2)^{*}$ \\
\hline 5 & $167.3(152.5 / 176.5)^{*}$ & $45.2(42.1 / 47.5)^{*}$ \\
\hline 6 & $142.1(132.1 / 158.7)^{* \wedge}$ & $45.2(42.0 / 47.0)^{*}$ \\
\hline 7 & $144.0(130.0 / 151.3)^{*}$ & $34.4(31.2 / 35.8)^{* \wedge}$ \\
\hline
\end{tabular}

Note: * ${ }^{*} \mathrm{p}<0.05$, compared with Group $1 ;{ }^{\wedge}-\mathrm{p}<0.05$, compared with Group 2.

The LDH and ALT activity in the blood plasma of the rats of group 4 increased by 3.9 and 2.0-fold, respectively, compared with the control group. Lipoic acid had generally negative results. Administration of lipoic acid only per os resulted in the activity indices of the studied cytolytic markers remaining at the same level as those in the blood plasma of rats of group 2 . The mixed administration of lipoic acid via injections followed by oral administration (group 6) lowered the LDH activity by $27 \%$ compared with group 2 . In the rats that were intraperitoneally injected with lipoic acid during the entire treatment (group 7), the ALT and LDH activity was lower by $15 \%$ and $26 \%$, respectively, compared with group 2. Thus, the cytoprotective effect of ademetionine was significant, while that of lipoic acid was mild but positive. As expected, drug administration by injection was significantly more effective than per os. However, intraperitoneal injection of ademetionine was more effective than the other tested drugs. The usage of methionine (per os) showed no protective effect; in fact, it may have turned the pathological process to its more severe course.

The indices of the antioxidant system in the blood demonstrated a decrease in CAT activity by $31 \%$ and an increase in GPO activity by $50 \%$ in rats of group 2 compared with the control group 1 (Table 2). Furthermore, we detected a decrease in GSH concentration in erythrocytes of group 2 by $29 \%$, compared with group 1 . Evaluation of these indices after treatment revealed no positive effects on the GSH concentration, whereas the CAT and GPO activity in erythrocytes from rats of groups 3-7 was generally closer to the control values. In rats injected with ademetionine or lipoic acid (intraperitoneally or in the mixed layout), the activity of both CAT and GPO revealed no statistically significant differences in comparison with the control. The oral administration of lipoic acid lowered the GPO activity in erythrocytes by 1.9 -fold, while the CAT activity was reduced by 2.6 fold compared with the control. Oral administration of methionine resulted in increased GPO activity similarly to group 2, but the CAT activity was lowered by 2.3-fold compared with the control and by 1.6-fold compared with group 2.

Examination of the DC and TC content in the blood plasma of test rats demonstrated the intensification of free-radical processes and the formation of primary products of oxidative modifications of biomolecules by chronic alcoholization. The DC content in the blood plas- ma of rats of group 2 increased by $67 \%$ [1.5 (1.4/1.7) $\mu \mathrm{mol} / \mathrm{L}]$, while the TC content increased by $35 \%[0.42$ $(0.40 / 0.46)$ C.U.] compared with the control $(p<0.05)$. In rats injected with ademetionine, the level of these parameters also significantly increased, but to a lower degree. The DC content in the blood plasma of the rats of group 3 increased by $44 \%$ [1.3 (1.2/1.4) $\mu \mathrm{mol} / \mathrm{L}]$, while the TC content increased by $25 \%$ [0.39 (0.35/0.41) C.U.] compared with the control. The injections of lipoic acid had the most significant antioxidant effect. The level of products of oxidative modifications of biomolecules in the blood plasma of rats of groups 5 and 6 compared with group 2 decreased by $20 \%$ and $10 \%$ for DC and TC, respectively. The intraperitoneal injections of lipoic acid (group 7) during the entire treatment decreased the levels of DC and TC to or lower than the control levels. Thus, oxidative stress plays an important role in the pathobiochemistry of chronic alcoholization. However, this role is not a major one.

Table 2

State of antioxidant markers in erythrocytes of rats suffering from chronic alcoholization [Me (p0.25/p0.75)]

\begin{tabular}{|c|c|c|c|}
\hline \multirow[b]{2}{*}{ Group } & \multicolumn{3}{|c|}{ Indices } \\
\hline & $\begin{array}{c}\text { CAT, } \\
\mathrm{mol} / \mathrm{L} / \mathrm{min}\end{array}$ & $\begin{array}{c}\text { GPO, } \\
\mathrm{mmol} / \mathrm{L} / \mathrm{min}\end{array}$ & $\begin{array}{c}\mathrm{GSH} \\
\mathrm{mmol} / \mathrm{mL}\end{array}$ \\
\hline 1 (control) & $\begin{array}{c}16.2 \\
(15.84 / 20.9)\end{array}$ & $\begin{array}{c}330.2 \\
(300.6 / 358.7)\end{array}$ & $\begin{array}{c}2.4 \\
(2.3 / 2.6)\end{array}$ \\
\hline 2 & $\begin{array}{c}11.2 \\
(10.54 / 14.0)^{*}\end{array}$ & $\begin{array}{c}496.6 \\
(423.1 / 507.1)^{*}\end{array}$ & $\begin{array}{c}1.7 \\
(1.5 / 1.9)^{*}\end{array}$ \\
\hline 3 & $\begin{array}{c}14.8 \\
(14.2 / 17.4)^{\wedge}\end{array}$ & $\begin{array}{c}340.0 \\
(300.5 / 360.2)^{\wedge}\end{array}$ & $\begin{array}{c}1.7 \\
(1.5 / 1.8)^{*}\end{array}$ \\
\hline 4 & $\begin{array}{c}6.9 \\
(6.2 / 7.6) * \wedge\end{array}$ & $\begin{array}{c}450.7 \\
(420.2 / 470.8) *\end{array}$ & $\begin{array}{c}1.7 \\
(1.6 / 1.9)^{*}\end{array}$ \\
\hline 5 & $\begin{array}{c}6.3 \\
(5.9 / 7.0) * \wedge \\
\end{array}$ & $\begin{array}{c}280.8 \\
(250.0 / 305.4)^{\wedge}\end{array}$ & $\begin{array}{c}1.9 \\
(1.8 / 2.2)^{\wedge}\end{array}$ \\
\hline 6 & $\begin{array}{c}24.8 \\
(20.3 / 26.0) * \wedge\end{array}$ & $\begin{array}{c}336.0 \\
(308.3 / 359.2)^{\wedge}\end{array}$ & $\begin{array}{c}1.9 \\
(1.8 / 2.1)^{*}\end{array}$ \\
\hline 7 & $\begin{array}{c}19.5 \\
(16.5 / 21.5)^{\wedge}\end{array}$ & $\begin{array}{c}342.1 \\
(310.0 / 360.0)^{\wedge}\end{array}$ & $\begin{array}{c}1.6 \\
(1.5 / 1.8)^{*}\end{array}$ \\
\hline
\end{tabular}

Note: ${ }^{*}-\mathrm{p}<0.05$ compared with Group $1 ;{ }^{\wedge}-\mathrm{p}<0.05$ compared with Group 2.

In the liver tissue, we observed increased GPO and CAT activity by 2 and 3.6-fold, respectively, in the chronic alcoholization group compared with the control, which can be considered to be the adaptive changes towards the developing oxidative stress (Table 3 ). The sharp increase in CAT activity may be caused by the participation of this enzyme in ethanol metabolism. The GSH concentration decreased in the liver of the rats of group 2 by $39 \%$ compared with the control. The ademetionine injections to the rats of group 3 reversed the effect of alcoholization on the activity of these enzymes, and it significantly increased the GSH concentration in the liver homogenate by $35 \%$ compared with group 2 . The lipoic acid administration in any of the studied layouts or the methionine administration did not increase the GSH concentration in the liver tissue. In addition, the activity of the antioxidant enzymes decreased in the rats of groups 4-7, compared with group 2. After methionine treatment the CAT activity decreased by 2.3-fold and the GPO activity decreased by $19 \%$ compared with group 2. However, lipoic acid had a smaller effect on the activity of these enzymes; the GPO activity decreased in rats of groups $5-7$ by $8 \%-28 \%$, and the CAT activity decreased by 2.1 -fold only in the rats that were intraperitoneally injected with lipoic acid. 
Table 3 lipoic acid. The methionine treatment of the rats of group

State of antioxidant markers in the liver of rats suffering from chronic alcoholization [Me (p0.25/p0.75)]

\begin{tabular}{|l|c|c|c|}
\hline \multirow{2}{*}{ Group } & \multicolumn{3}{|c|}{ Indices } \\
\cline { 2 - 4 } & $\begin{array}{c}\text { CAT, } \\
\mathrm{mmol} / \mathrm{L} / \mathrm{mg}\end{array}$ & $\begin{array}{c}\mathrm{GPO} \\
\mathrm{mmol} / \mathrm{L} / \mathrm{mg}\end{array}$ & $\begin{array}{c}\mathrm{GSH} \\
\mathrm{mmol} / \mathrm{mg}\end{array}$ \\
\hline 1 (control) & $1.4(1.2 / 1.6)$ & $\begin{array}{c}10.3 \\
(9.8 / 10.8)\end{array}$ & $3.3(3.0 / 3.4)$ \\
\hline 2 & $\begin{array}{c}5.1 \\
(4.5 / 6.2)^{*}\end{array}$ & $\begin{array}{c}20.3 \\
(19.0 / 21.1)^{*}\end{array}$ & $\begin{array}{c}2.0 \\
(1.9 / 2.1)^{*}\end{array}$ \\
\hline 3 & $\begin{array}{c}0.9 \\
(0.8 / 1.3) \wedge\end{array}$ & $8.8(8.4 / 9.5)^{\wedge}$ & $\begin{array}{c}2.7 \\
(2.6 / 2.9)^{* \wedge}\end{array}$ \\
\hline 4 & $\begin{array}{c}2.2 \\
(1.9 / 2.4)^{* \wedge}\end{array}$ & $\begin{array}{c}16.4 \\
(16.0 / 17.0)^{* \wedge}\end{array}$ & $\begin{array}{c}1.8 \\
(1.7 / 2.0)^{*}\end{array}$ \\
\hline 5 & $\begin{array}{c}7.0 \\
(6.5 / 7.4)^{* \wedge}\end{array}$ & $\begin{array}{c}14.5 \\
(14.1 / 15.2)^{* \wedge}\end{array}$ & $\begin{array}{c}2.1 \\
(1.9 / 2.2)^{*}\end{array}$ \\
\hline 6 & $\begin{array}{c}4.4 \\
(4.0 / 4.7)^{*}\end{array}$ & $\begin{array}{c}14.8 \\
(14.2 / 15.5)^{* \wedge}\end{array}$ & $\begin{array}{c}2.1 \\
(2.0 / 2.3)^{*}\end{array}$ \\
\hline 7 & $\begin{array}{c}2.4 \\
(2.0 / 2.7)^{* \wedge}\end{array}$ & $\begin{array}{c}18.7 \\
(18.2 / 19.4)^{*}\end{array}$ & $\begin{array}{c}2.0 \\
(1.9 / 2.3)^{*}\end{array}$ \\
\hline
\end{tabular}

Note: * $-\mathrm{p}<0.05$ compared with Group $1 ;{ }^{\wedge}-\mathrm{p}<0.05$ com pared with Group 2.

Examining the membrane potential of mitochondria sampled from rat livers revealed the development of mitochondrial dysfunction by chronic alcoholization. The average membrane potential in the mitochondrial suspensions sampled from the liver of rats of group 2 was decreased by $37 \%(p<0.05)$ compared with the control [180.2 (172.3/185.6) mV]. Similar values (100.8$110.3 \mathrm{mV}$ on average) were observed in mitochondrial suspensions sampled from the liver of rats injected with
4 caused a more severe disturbance of energy metabolism, as the membrane potential in suspensions from this group decreased by $63 \%(p<0.05)$ compared with the control. Only the ademetionine injections provided effective protection for mitochondria - the membrane potential of mitochondrial suspensions from group 3 decreased only by $11 \%$ [160.6 (153.6/166.5) mV].

Conclusions. The comparative analysis of the effectiveness of various sulphur-containing remedies on chronic alcoholization revealed significant advantages of intraperitoneal injections of ademetionine, which had hepatoprotective antioxidant effects represented by the maintenance of functional mitochondria. In contrast, the essential amino acid, methionine, which is the precursor of ademetionine, revealed no cytoprotective effects under the experimental conditions. The reason for this may be related to methionine administration under impaired liver function, including the liver bioenergy, manifested by the decreased mitochondrial membrane potential. It is also likely that the formation of its active form requiring ATP-consumption was disturbed. This hypothesis was indirectly supported by the aggravation of mitochondrial dysfunction after methionine administration to rats under alcoholization. Hence, methionine usage as a preventive measure seems to be justified during remission. The lipoic acid injections demonstrated significant antioxidant effects, but its cytoprotective effect was mild. On the basis of our findings, we concluded that the substances tested here mainly improved metabolic disorders induced by chronic alcoholization via maintenance of the detoxification and biosynthetic functions of the liver.

\section{Disclosures:}

The authors declare no conflict of interest.

\section{Acknowledgments:}

This work was supported by the State Task of the Ministry of Health Care of the Russian Federation by state assignment (28.01.2015, part 1, chapter 1).

We thank Michal Bell, PhD, from Edanz Group (www.edanzediting.com/ac) for editing a draft of this manuscript.

\section{References}

1. Bykov I. M., Popov K. A., Egorova I. A., Storozhuk A. P. Assessment of indicators of the thiol metabolism of blood plasma of patients with inflammatory diseases of the small pelvis organs at antioxidant correction. Medical News of North Caucasus. 2018:13(2):402-406.

https://doi.org/10.14300/mnnc.2018.13062

2. Popov K. A., Bykov I. M., Tsymbalyuk I. Yu., Bykov M. I., Sidorenko A. N. [et al.] Changes in state of the thiol linkages of an antioxidant system during ischemia and reperfusion, against a background of vascular exclusion in the rat liver. Medical News of North Caucasus. 2018;13(3): 525-529. https://doi.org/10.14300/mnnc.2018.13096

3. Jung Y. S. Metabolism of sulfur-containing amino acids in the liver: A link between hepatic injury and recovery. Biol. Pharm. Bull. 2015;38(7):971-974. https://doi.org/10.1248/bpb.b15-00244

4. Dolgareva S. A., Sorokin A. V., Konoplya N. A., Bushmina O. N., Bystrova N. A., Ovod A. I. The use of immunomodulators, antioxidants and hepatoprotectors for the correction of the liver, erythrocites and the immune system disorders in chronic ethanol intoxication. Biomedical Chemistry. 2018;64(4):360-367

\section{https://doi.org/10.18097/PBMC20186404360}

5. Raikhelson K. L., Kondrashina E. A. Ademethionine in the treatment of fatigue in liver diseases: a systematic review. Archive. 2019;91(2):134-142. https://doi.org/10.26442/00403660.2019.02.000130

6. Onaolapo O. J., Adekola M. A., Azeez T. O., Salami K., Onaolapo A. Y. I-Methionine and silymarin: A comparison of prophylactic protective capabilities in acetaminopheninduced injuries of the liver, kidney and cerebral cortex. Biomed. Pharmacother. 2017;85:323-333. https://doi.org/10.1016/j.biopha.2016.11.033
7. Hosseinpour-Arjmand S., Amirkhizi F., Ebrahimi-Mameghani M. The effect of alpha-lipoic acid on inflammatory markers and body composition in obese patients with non-alcoholic fatty liver disease: A randomized, double-blind, placebocontrolled trial. J. Clin. Pharm. Ther. 2019;44(2):258-267. https://doi.org/10.1111/jcpt.12784

8. Valdecantos M. P. Pérez-Matute P., Prieto-Hontoria P Moreno-Aliaga M. J., Martínez J. A. Impact of dietary lipoic acid supplementation on liver mitochondrial bioenergetics and oxidative status on normally fed Wistar rats. Int. J. Food Sci. Nutr. 2019;15:1-11.

https://doi.org/10.1080/09637486.2019.1572716

9. Belenichev I. F., Kucher T. V. The deprivation of glutathione system in the cytosol and mitochondria of rat brain with chronic alcohol intoxication: protective effects of thiol antioxidants. Bulletin of problems biology and medicine. 2016;1(4):111-116.

10. Shulkin L. M., Kosenko N. A., Kosenko V. G., Ageev M. I., Shulkin M. Z. Clinical overview remission of alcohol dependence. Kuban Scientific Medical Journal. 2015;2:153159.

11. Volchegorskiĭ I. A., Rassokhina L. M., Miroshnichenko I. Yu. Insulin-potentiating action of antioxidants in experimental diabetes mellitus. Problemi Endocrinologii. - Problems of endocrinology. 2010;56 (2):27-35.

12. Karpishchenko A. I. Handbook. Medical Laboratory Technology. Sankt-Petersburg: Intermedika, 2002.

13. Egorova M. V., Afanasyev S. A. Isolation of mitochondria from cells and tissues of animals and human: Modern methodical approaches. Sibirskij medicinskij žurnal. - Siberian Medical Journal. 2011;26(1):22-28.

14. Cheshchevik V. T. Mitochondrial membrane potential of rat hepatocytes under toxic injury. Izvestiya Nacional'noj akademii nauk Belarusi. Seriya biologicheskih nauk. - Pro- 
ceedings of the National Academy of Sciences of Belarus, Biological Series. 2010;2:75-80.

15. Zorova L. D., Popkov V. A., Plotnikov E. J., Silachev D. N., Pevzner I. B. [et al.] Roles of Mitochondrial Membrane Po- tential. Membrane and Cell Biology. 2017;34(6):93-100. https://doi.org/10.7868/S0233475517060020

\begin{abstract}
About authors:
Bykov Ilia Mikhaylovich, MD, PhD, Professor, Head of the Department of fundamental and clinical biochemistry; tel.: +79182125530; e-mail: ilya.bh@mail.ru

Berberidi Hristina Panaetovna, postgraduate student of the Department of fundamental and clinical biochemistry; tel.: +79189045555; e-mail: hristy@mail.ru

Popov Konstantin Andreevich, PhD, Assistant of the Department of fundamental and clinical biochemistry; tel.: +79288824941; e-mail: naftalin444@mail.ru

Ermakova Galina Alekseevna, PhD, Assistant of the Department psychiatry; tel.: +79182125530; e-mail: ilya.bh@mail.ru

Tsymbalyuk Igor Yuryevich, Laboratory Assistant of the Department of surgery № 2; tel.: +79284300769; e-mail: igor_ts@inbox.ru

Esaulenko Elena Evgenievna, MD, PhD, Professor of the Department of fundamental and clinical biochemistry;

tel.: +79184353523; e-mail: esaulenkoe@bk.ru

Denisova Yana Evgenievna, postgraduate student of the Department of fundamental and clinical biochemistry; tel.: +79182765890; e-mail: iana.denisova.1994@mail.ru

Azimov Erustam Adamovich, postgraduate student of the Department of fundamental and clinical biochemistry; tel.: +79183414969; e-mail: ilya.bh@mail.ru
\end{abstract}

\title{
MORPHOFUNCTIONAL CHANGES IN THE LIVER AND THE STATE OF THE RAT BLOOD COAGULATION SYSTEM IN DEVELOPMENT OF REPERFUSION SYNDROME
}

Pisarev A. A. ${ }^{1}$, Anisimova L. V. ${ }^{1}$, Fomochkina I. I. ${ }^{1}$, Kubyshkin A. V. ${ }^{1}$, Kuzichkin D. S. ${ }^{2}$, Shramko Ju. I. ${ }^{1}$, Kharchenko V. Z. ' ${ }^{1}$, Golubinskaya E. P. ${ }^{1}$

${ }^{1}$ Medical Academy named after S. I. Georgievsky of V. I. Vernadsky Crimean Federal University, Simferopol, Russian Federation

2 Institute of Biomedical Problems of RAS, Moscow, Russian Federation

\section{МОРФОФУНКЦИОНААЬНЫЕ ИЗМЕНЕНИЯ ПЕЧЕНИ И СОСТОЯНИЕ СИСТЕМЫ КОАГУАЯЦИИ КРОВИ КРЫСЫ ПРИ РАЗВИТИИ РЕПЕРФУЗИОННОГО СИНАРОМА}

А. А. Писарев ${ }^{1}$, А. В. Анисимова ', И. И. Фомочкина ${ }^{1}$, А. В. Кубышкин ${ }^{1}$, А. С. Кузичкин ${ }^{2}$, Ю. И. Шрамко ${ }^{1}$, В. 3. Харченко ${ }^{1}$, Е. П. Голубинская ${ }^{1}$

1 Мелицинская акалемия им. С. И. Георгиевского Крымского фелерального
университета им. В. И. ВернаАского, Симферополь, Российская ФеАерация
2 Институт меАико-биологических проблем РАН, Москва, Российская ФеАерация

Disseminated intravascular coagulation leads to the development of multiple organ failure syndromes with a mortality rate higher than $50 \%$. We examined the pathogenetic mechanisms of formation of systemic reperfusion syndrome in a rat model of reperfusion syndrome for 6,12 , and 24 hours. A total of 60 white Wistar rats, with a weight of 180-200 g, were studied. We found that morphological changes in the liver were manifested by formation of triggers for hepatocyte damage, including activation of apoptosis and initiation of pro-inflammatory damage pathways. These changes did not lead to severe alterations in functional activity of the liver. Disturbances in the blood coagulation system that developed with reperfusion syndrome with a potential threat of developing DIC were associated with increased consumption of coagulation factors. These disturbances in the blood coagulation system were also associated with inhibition of synthetic function of the liver to a lesser extent. 